\title{
Learner Creativity and Performance in Written Narrative Tasks
}

\author{
Reza Pishghadam (Corresponding author) \\ English Department, Ferdowsi University of Mashhad \\ PO box 91779-48974, Park Square, Ferdowsi University Mashhad, Iran \\ Email: rpishghadam@yahoo.com \\ Fatemh Javdan Mehr \\ English Department, Ferdowsi University of Mashhad \\ PO box 91779-48974, Park Square, Ferdowsi University Mashhad, Iran \\ Email: f.javdanmehr@gmail.com
}

\author{
Received: March 27, 2011 \\ Accepted: May 12, $2011 \quad$ Published: October 1, 2011 \\ doi:10.5430/wje.v1n2p115 \\ URL: http://dx.doi.org/10.5430/wje.v1n2p115
}

\begin{abstract}
This study aims at examining the relationship between learner creativity and performance in written narrative tasks in the context of Iranian EFL students. To this end, a sample of 222 EFL students from four universities in Mashhad (Iran) participated in this study. Our study involved measuring the participants' creativity using creativity test and eliciting written narrative performance from the participants with the help of a narrative task. The task involved two parts of narrating a story on the basis of a picture and writing a memory. We used correlation and ANOVA to analyze the data. The results exhibited a significant relationship between learners' performance in written narrative tasks and their total creativity and also with some sub constructs of creativity: fluency, originality and flexibility. Finally, the results were discussed in the context of language teaching and learning.
\end{abstract}

Keywords: Learner creativity, Fluency, Originality, Flexibility, Elaboration, Written narrative task

\section{Introduction}

While the influence of many cognitive variables such as language aptitude, intelligence and various learning and thinking styles have been researched widely (Dewaele \& Furnham, 1999; Gardner \& MacIntyre, 1992, 1993; Oxford \& Ehrman, 1993; Skehan, 1989, 1991), investigating the effects of creativity and its relationship with different aspects of teaching and learning has been just recently coming to the focus of scholars' attention. The changing methods of second language instruction and prominence of communicative methods and task-based language teaching, which employ tasks that require students to use their imagination, made researchers pay more attention to creativity (Albert, 2008). Developing critical and creative skills and nurturing citizens with creativity and innovative capacity are becoming worldwide because of the knowledge-based economy today (MacDonald, 2005)and increasing global concern with 21st century skills ( $\mathrm{Li}, 2010)$. In an attempt to define creativity, Piirto (2004) found that the root of the words "create" and "creativity" comes from the Latin creâtus and creâre, meaning "to make or produce". With regard to creativity, researchers agree that creativity refers to the generation of ideas or products that are original, valuable or useful (Amabile, 1996; Sternberg \&Lubart, 1999).

Although the qualities of creative people might be advantageous in any language task, it seems that narrative tasks, which obviously rely on learners' imagination, might intensify the effect of creativity on language performance. Therefore, although the imaginativeness or creativity of the stories cannot be measured directly, it is believed that narrative tasks would be best fitted for doing exploratory research on the relevance of creativity and output (Albert \& Kormos, 2004). In fact, we believe that language tasks, especially open-ended ones like narrative tasks, where there is no correct solution but a large number of solutions are possible, could be more suitable for foreign language learners.

Thus in this study, we attempt at bridging this gap by carrying out research on the relationship between learner creativity and the performance of written narrative tasks in the community of Iranian students whose results can be implemented in the improvement of the foreign language instruction. 


\section{Theoretical Framework}

Creativity is one of the psychological constructs that both professionals and laypeople seem to understand but it is not easy to define. That may be because of its overlap with traditional individual differences categories (Dornyei, 2005), e.g. it is one of the three basic aspects of Sternberg theory of successful intelligence (Sternberg, 2002). However, creativity extends beyond the intellectual domain. Recent personality theories usually include a prominent creativity component. In 2004 Runco summarized the psychological literature of creativity in a review in which he mentioned that the scientific study of creativity was initiated by Guilford (1950) where he stated a list of cognitive processes involved in creativity; however, he later started to focus on divergent thinking as the prime cognitive component of creativity (Guilford, 1959). Nonetheless, some studies suggested that divergent thinking should not be identified as creative thinking (e.g. Nicholls, 1972).

Creativity was always referred to as the ability of producing original, novel and useful work or idea (Amabile, 1996; Sternberg \&Lubart, 1999). In 1999, The National Advisory Committee on Creative and Cultural Education (NACCCE) recognized four characteristics of creative processes: behaving imaginatively, purposeful activity, originality, and utility. They define creativity as: "Imaginative activity fashioned so as to produce outcomes that are both original and of value" (p.30). In the same vein, Torrance (1966) believed that creativity has the following constituents: (1) creative fluency, the ability to produce a large number of ideas; (2) flexibility, the ability to produce a large variety of ideas; (3) originality, the ability to produce unusual, unique ideas or ideas which are statistically infrequent and (4) elaboration, the ability to develop or embellish ideas and to produce many details.

In the educational domain, creativity teaching includes the development of a combination of abilities, skills, attitudes, motivation, knowledge, and other attributes (Starko, 2010; Kaufman, 2009; Runco, 2003, 2004, 2007; Sternberg, 2003).However, recently the development of creative potentials of students is emphasized instead of their immediate creative achievements or performance. NACCCE (1999) set out proposals to support the development of creativity in education in schools, claiming that creativity in education is not just an opportunity, but a necessity. Nowadays, it is an international trend to integrate creativity in curriculum frameworks. With this increasing global concern, reforming the structure of education to include much greater focus on developing critical and creative skills is happening across the world including Asia. Recently, countries of China, Taiwan, Singapore, South Korea, Hong Kong, and some other Asian countries in the support of their governments are trying to implement curriculum reforms in a top-down process, which emphasize creativity development in the primary and secondary schools (Cheng, 2011). To this end, they are in need of effective methods to infuse creativity elements into their regular classrooms (Cheng, 2004).

A shift in learning requires a change in teaching practices and methods. People use and follow different ways of collecting and organizing information into useful knowledge. Issues such as time constraints, lack of useful resources, teachers' experience and so on, make it extremely difficult for teachers to cater for the individual differences (Cheng, 2010). This is why innovative teaching is addressed, which is the implementation of new teaching methods and practices aimed at fostering teachers' and students' creativity. It is important that the education policy makers note that the starting points of creativity reforms in Asian places may be quite different from that of some Western countries. Cheng (2010) in his study noticed that the cultural level issues besides the individual level and system level problems are the origin of the teachers' tensions and dilemmas in this new curriculum.

One of the areas in which it seems creativity is a relevant topic is the narrative genre. As Johnstone (2008) states, the concept of narrative has become a significant part of the repertoire of the social sciences since the mid-1950s and has been one of the major areas of research within linguistics. Various areas of narrative from its formal structure to the use of it in the presentation of self have been explored by the researchers (O"zyllırım, 2009).A narrative, by definition, refers to the recitation a fictional or real account of an event or an experience sequentially (Justice, Bowles, Pence, \& Gosse, 2010).Narrative is one type of discourse with the classification of oral and written language.Spoken discourse analysis, which is concerned with speech, is studied more extensively than written discourse analysis (Stubbs, 1997; van Dijk, 1997; Atkinson, 1991).

Similarly, as indicated by Johnstone (2008), most studies on narratives concentrate on the investigation of narrative structures in oral language. In a study, O"zylldrrm (2009) investigated the narrative structures in the oral language in comparison with the written version. He concluded the structure of personal experience narratives as a specific genre. Narrative tasks are well-established and frequently researched task types (Foster\& Skehan, 1996; Skehan\& Foster, 1999; Robinson, 1995). They usually involve the creation of a story in response to some kind of stimulus: a picture strip or a short film so this task type seems ideal as far as the manifestation of creativity is concerned. Sharples (1999) illustrated that because writing is an open-ended design process it is comparable to creative design rather than problem solving which is without settled stages, specific results or a defined goal. Vass (2007) also agrees with Sharples in this 
assumption that writing as creative design builds on creativity. He studied the role of emotions in children's creative writing and indicated the centrality of emotions in the creative writing and the role of emotion-driven thinking in phases of shared engagement. Also Rojas-Drummond, Albarrán and Littleton (2008) studied how primary school children learn to collaborate and collaborate to learn on creative writing projects by using diverse cultural artifacts including orality, literacy and ICT. In another study, Chen \& Zhou (2010) explored the ways of improving the creative writing strategies of young Chinese writers by using the graphical representations to stimulate and help the development of writing skills. They found that when Chinese children faced those Chinese characters they were not able to write, they used creative writing skills to communicate. The findings of the study have implications for the teaching of writing as well as the use of pictures in teaching young learners. The daily increasing studies in the field of creativity show its centrality to learning and the many different ways in which this key concept can be investigated.

\section{Purpose of the Study}

The present research aimed to investigate the relationship between written narrative task performance and the features of learner creativity (fluency, elaboration, flexibility and originality), while controlling for the differences in the participants' level of proficiency. Since written narrative tasks generally involve storytelling based on some cues (e.g. pictures), this task type seems to prepare an opportunity for learners to use their imagination and creativity. Therefore, in this study we attempt to answer the following two questions:

Does creativity play any role in written narrative tasks?

Does creativity make any difference in high, mid, and low groups with respect to written narrative tasks?

\section{Method}

\subsection{Participants and setting}

A sample of 408 EFL (English as a Foreign Language) students aging from18 to 31 years old from four universities in Mashhad (a city in Iran) participated in this study. The data of 102 participants were incomplete, so they were excluded from the study. From the rest 306, 222 (82 males \& 140 females) of almost the same level of language proficiency were chosen for further analysis. To select the homogenized participants, we chose the participants whose narrative scores were between $-2 \mathrm{SD}$ and $+2 \mathrm{SD}$.

\subsection{Instrumentation}

\subsubsection{Written narrative task}

In an attempt to study the relationship between creativity and task performance, written narrative tasks were chosen, as this task type seemed to offer a good opportunity for learners to demonstrate their creativity. Therefore, a written narrative task was performed by the participants in this study. The task involved two parts of narrating a story on the basis of a picture and writing a memory of their first days at the university. We allotted 15 minutes for the former and another 10 minutes for the latter task. The allocated time was the same for all the groups in different universities. To calculate the reliability, two raters were asked to score the students' narratives. The results of Pearson product-moment correlation analysis exhibited a high amount of reliability $(\mathrm{r}=.91, \mathrm{p}<.01)$.

\subsubsection{Creativity test}

The standardized creativity test (Auzmendi, Villa, \& Abedi,1996) which was used in this study is a questionnaire consisted of 60 multiple choice questions with 3 choices of a, b, c (from low to high creativity). The scoring of the creativity test is in the way that $1,2,3$ point(s) is allotted to the 3 choices of a, b, c respectively. Mahmoodi (2001) administered this test to a group of 420 lay people and artists in Tehran, Iran whose results showed the reliability of .88 (using Cronbach Alpha method) and a correlation of .46 with Torrance test (1966) of creativity, which reflects the plausible validity of the test. This test measures learner creativity as a total creativity score and likewise gives us a score for each of its four parts of fluency, elaboration, originality and flexibility separately.

In this study, the Cronbach's Alpha for total creativity was equal to 0.85, which shows a high reliability. Moreover, reliability coefficient for creative fluency was 0.66 , for creative originality 0.68 , for creative flexibility 0.63 , and for creative elaboration it was 0.63 .

\subsection{Procedure}

The data collection started in April 2010 and finished in June 2010. The instruments were administered to EFL students from four universities. Participants were students of first, second, third and fourth grade at university, so we had to administer the instruments separately to each group at the end of their university classes. Researchers were present all the time trying to keep the conditions consistent, especially controlling the allocated time for the tasks. After collecting 
the data, it was entered into and processed with SPSS 16 program. In this study, we were trying to find out the relevance of learner creativity to their performance in written narrative tasks. To this end, we first used correlation and then ANOVA. To use ANOVA, we first divided the participants into three group of 74 subjects as high group, mid group and low group based on their narrative scores. Finally, Scheffe test was used to pinpoint the locations of differences.

\section{Results}

To measure the amount of relationship between creativity and narrative task, we employed Pearson product-moment correlation. The results of the correlational analysis are summarized in Table 1. The findings indicate that only one component of creativity is associated with narrative score: creative fluency $(\mathrm{r}=.15, \mathrm{p}<.05)$. No significant correlations were found between narrative score and creative elaboration, creative originality, creative flexibility and the total creativity score.

$<$ Table 1 about here $>$

To further analyze the data, we utilized ANOVA. Table 2a illustrates a significant difference among 3 groups regarding the total creativity scores $(\mathrm{F}=5.215, \mathrm{P}<.05)$. Also, according to Table $2 \mathrm{~b}$ which shows the results of Scheffe test, high group (mean: 139.2432) was rated as the highest in total creativity. Mid group (mean: 134.6216) received the second lowest ranking and the low group (mean: 132.9054) received the lowest ranking in total creativity.

$<$ Tables $2 \mathrm{a} \& 2 \mathrm{~b}$ about here $>$

High $>$ Mid $>$ Low

As the results of Table 3 show, there is no significant difference $(\mathrm{F}=1.808, \mathrm{P}>.05)$ among three groups with regard to creative elaboration.

$<$ Table 3 about here $>$

Table 4a exhibits a significant difference among the 3 groups with regard to the creative originality scores $(\mathrm{F}=4.783, \mathrm{P}$ $<.05$ ). As evident in Table 4b, the high group (mean: 36.8378) received the highest ranking. Mid group (mean: 36.0135 ) received the second lowest ranking and the low group (mean: 34.7162 ) was rated as the lowest in creative originality.

$<$ Tables $4 \mathrm{a} \& 4 \mathrm{~b}$ about here $>$

High $>$ Mid > Low

Table 5a shows a significant difference among the 3 groups regarding the creative flexibility scores $(\mathrm{F}=3.091, \mathrm{P}<.05)$. Also, according to Table 5b, high group (mean: 27.2703) was rated as the highest in creative flexibility. Mid group (mean: 26.2027) received the second lowest ranking and the low group (mean: 26.1081) received the lowest ranking in creative flexibility.

$<$ Tables $5 \mathrm{a} \& 5 \mathrm{~b}$ about here $>$

High > Mid / Low

Table 6a illustrates a significant difference among the 3 groups regarding the creative fluency scores $(\mathrm{F}=3.059, \mathrm{P}<.05)$. Also, according to Table 6b, the high group (mean: 51.7297) was rated as the highest in creative fluency. Mid group (mean: 50.1892) received the second lowest ranking and the low group (mean: 49.8243) received the lowest ranking in creative fluency.

$<$ Tables $6 \mathrm{a} \& 6 \mathrm{~b}$ about here $>$

High $>$ Mid $>$ Low

\section{Discussion}

Considering how to manipulate the data, the researchers came up with different results. The results of correlation analysis except for creative fluency showed no significant correlation between creativity and written narrative performance. However, when the participants were divided into different groups, the results of ANOVA indicated a significant difference among the three groups of proficiency regarding the creative features except for creative elaboration which exhibited no significant difference. 
Sternberg (2002) believed that creativity is an important determiner of language acquisition. The more proficient a language learner is, the more familiar they are with the language lexis and structures, therefore, in the writing task they can write longer essays. This is consistent with the concept of creative fluency as was defined by Torrance (1966): the ability to produce a large number of ideas. Albert and Kormos (2004) also indicated this point in their research conclusion; they mentioned that students who did better in a creativity test were found to have more production in their narrative task, thus in a foreign language setting, they might create more opportunities for themselves to use the language.

Moreover, as the results of this study showed there is a significant difference among the three groups of proficiency regarding their creative flexibility. It implies that the more proficient learners can conveniently come up with larger variety of vocabularies, which can be the result of creative flexibility.

Creative originality, the ability to produce unusual, unique ideas or ideas which are statistically infrequent is another feature which is shown to be higher in more proficient learners. It is quite justifiable considering the more knowledge they have in the language. This result confirms that of Otto (1998) who found a significant positive relationship between creativity and second language learner performance in the way that in communicative tasks learners used their imagination to construct their own ideas. These findings complement the series of studies conducted by Ehrman and her colleagues (Ehrman, 1996; Ehrman \& Oxford, 1995; Grigorenko, Sternberg, \& Ehrman, 2000) who claim that the ability to cope with novelty, that is the ability to produce original ideas, is an important characteristic that affects the success of language learning.

According to our findings, the only constituent of creativity which showed no significant difference among the three groups of proficiency is creative elaboration. Torrance (1966) defined it as the ability to develop ideas and to produce many details. This result is probably due to the situation in which our research was conducted i.e. limited time allocated to participants for the written narrative tasks. In fact, to finish their work in the given time, they could not embellish their writing.

In a nutshell, the notion that creativity has positive impact on learning and proficiency seems more acceptable as it can be claimed that language use is a creative act: we transform thoughts into language that can be heard or seen and likewise we are capable of producing sentences and even long texts that we have never heard or seen before.

Applying the findings of our study and other studies in this area, we can design consciousness-raising programs to make learners more aware of their potential creativity. It is essential that we focus our teaching on facilitating our student's education toward being more creative. As Chen and Zhou (2010) stated, for creative thinking teachers should offer students space and opportunity to support their insightful and associative thinking. In such a situation independent creativity will emerge.

Moreover, information gained about the interplay of individual differences and various aspects of task performance could contribute to pedagogical decisions during task implementation and could help the selection of language teaching and testing tasks. Publishers and materials developers can include specific tasks in the textbooks with the aim of enhancing creative thinking. Tasks that involve the use of imagination and the generation of new ideas might provide creative learners with more chance to practice and produce more comprehensible output, which could lead to greater success in second language acquisition. This will require a shift of pedagogy, moving towards students' centeredness and the idea of cooperative learning as a means to foster not only creativity but also other skills, such as learning to learn skills, which will in turn equip them to be able to compete in a global community and economy. In a recent study, Cheng (2011) claimed that an active, playful, self-actualizing learning style, which emphasizes deeper understanding and daily-life application of science knowledge, encourages creative appreciation, alternative thinking, curiosity, confidence, and initiation in learning will be favored by students in the Asian contexts.

All in all, teachers are key figures in implementing change; they can empower students to become more responsible for their own learning. For instance, the conditions teachers set especially for writing development leave space to inspire children's independent thinking and encourage them to communicate through multiple ways. But the point is that teachers themselves need support to understand and accept creativity in their practices. In this regard, further studies can be planned to scrutinize the role of teachers in nurturing creativity, as well as possible ways of enhancing teachers' tendencies to implement more creative methods and tasks in their classrooms. Another possible research direction could involve studying the tasks more likely to develop learners' creativity. As a matter of fact, creativity is a concept that has a lot of capacity for being explored from different aspects in the realm of language teaching and learning. 


\section{References}

Albert, A., \& Kormos, J. (2004). Creativity and narrative task performance: An exploratory study. Language learning, 54, 277-31. http://dx.doi.org/10.1111/j.1467-9922.2004.00256.x

Amabile, T.M. (1996). Creativity in context. Update to the social psychology of creativity. Boulder, CO: West view Press.

Atkinson, D. (1991). Discourse analysis and written discourse conventions. Annual Review of Applied Linguistics 11, 57-76. http://dx.doi.org/10.1017/S0267190500001951

Auzmendi, E., Villa, A., \& Abedi, J. (1996). An empirical study of the reliability and validity of a newly constructed creativity instrument. The Creativity Research Journal, 9, 1, 89-95. http://dx.doi.org/10.1207/s15326934crj0901_8

Chen, S., \& Zhou, J. (2010). Creative writing strategies of young children: evidence from a study of Chinese emergent writing. Thinking Skills and Creativity, 5. 138-149. http://dx.doi.org/10.1016/j.tsc.2010.09.002

Cheng, V.M.Y. (2011). Infusing creativity into classroom of Eastern context: Evaluations from student perspectives. Thinking Skills and Creativity,6. 67-87. http://dx.doi.org/10.1016/j.tsc.2010.05.001

Cheng V.M.Y. (2010) Tensions and dilemmas of teachers in creativity reform in a Chinese context. Thinking Skills and creativity, 5,120-137. http://dx.doi.org/10.1016/j.tsc.2010.09.005

Cheng, V. M. Y. (2004). Progress from traditional to creativity education in Chinese societies. In S. Lau, A. N. N. Hui, \& G. Y. C. Ng (Eds.), Creativity: When East meets West. Singapore: World Scientific. http://dx.doi.org/10.1142/9789812567192_0007

Curriculum Development Council (2002). Science education: Key learning area curriculum guide (primary1-secondary3). Hong Kong: Curriculum Development Council.

Dewaele, J.M., \&Furnham, A. (1999). Extraversion: The unloved variable in applied linguistic research, Language Learning, 49, 509-544. http://dx.doi.org/10.1111/0023-8333.00098

Dornyei, Z. (2005). The psychology of the language learner. Mahwah NJ: Lawrence Erlbaum Associates, Inc.

Ehrman, M. E. (1996). Understanding second language learning difficulties. Thousand Oaks, CA: Sage.

Ehrman, M. E., \& Oxford, R. L. (1995). Cognition plus: Correlates of language learning success. The Modern Language Journal, 79. 67-89. http://dx.doi.org/10.2307/329394

Foster, P., \& Skehan, P. (1996). The influence of planning and task type on second language performance. Studies in Second Language Acquisition 9, 12-20.

Gardner, R.C., \& MacIntyre, P.D. (1992).A student's contributions to second language learning. Part I: Cognitive variables. Language Teaching, 25, 211-220. http://dx.doi.org/10.1017/S026144480000700X

Gardner, R.C., \&MacIntyre, P.D. (1993).A student's contributions to second language learning. Part II: Affective variables. Language Teaching, 26, 1-11. http://dx.doi.org/10.1017/S0261444800000045

Grigorenko, E. L., Sternberg, R. J., \& Ehrman, M. E. (2000). A theory based approach to the measurement of foreign language learning ability: The Canal F theory and test. The Modern Language Journal, 84. 390-405. http://dx.doi.org/10.1111/0026-7902.00076

Guilford, J. P. (1950). Creativity. American Psychologist, 5, 444-454. http://dx.doi.org/10.1037/h0063487

Guilford, J. P. (1959). Three faces of intellect. American Psychologist, 14, 469-479. http://dx.doi.org/10.1037/h0046827

Johnstone, B. (2008). Discourse Analysis. $2^{\text {nd }}$. Ed. Oxford: Blackwell.

Justice, L. M., Bowles, R., Pence, K., \& Gosse, C. (2010). A scalable tool for assessing children’ s language abilities within a narrative context The NAP (Narrative Assessment Protocol). Early Childhood Research Quarterly, 25, 218-234.

Kaufman, J.C. (2009). Creativity 101. New York: Springer Pub. http://dx.doi.org/10.1037/a0013688

Kaufman J.C., \& Beghetto R.A. (2009). Beyond Big and Little: The Four C Model of Creativity. Review of General Psychology, 13, 1-12.

Li, L. (2010). Introduction to the special issue: 'Thinking skills and creativity: SE Asian perspectives'. Thinking Skills and Creativity, 5, 1-2. http://dx.doi.org/10.1016/j.ecresq.2009.11.002

Mahmoodi Gh. (2001). Barresie rabeteye khallaghiate honari va raftare nabehanjar, Faslname Danesh va Pazhoohesh 
Dar Ravanshenasi, 6, 43-44.

National Advisory Committee on Creative and Cultural Education (NACCCE) (1999).All Our Futures: Creativity, Culture and Education. London: Department for Education and Employment.

Nicholls, J.G. (1972). Creativity in the person who will never produce anything original and useful: The concept of creativity as a normally distributed trait. American Psychologist, 27, 717-727. http://dx.doi.org/10.1037/h0033180

Otto, I. (1998).The relationship between individual differences in learner creativity and language learning success.TESOLQuarterly, 32(4), 763-773. http://dx.doi.org/10.2307/3588011

Oxford, R.L., \& Ehrman, M.E. (1993).Second language research on individual differences. Annual Review of Applied Linguistics, 13, 188-205. http://dx.doi.org/10.1017/S0267190500002464

O“zyıldırım, I. (2009). Narrative analysis: An analysis of oral and written strategies in personal experience narratives, Journal of Pragmatics, 4, 1209-1222.

Piirto, J. (2004). Understanding Creativity. Scottsdale, AZ: Great Potential Press.

Reilly R.C. (2008). Is expertise a necessary precondition for creativity? A case of four novice learning group facilitators. Thinking Skills and Creativity, 3, 59-76. http://dx.doi.org/10.1016/j.tsc.2008.02.002

Robinson, P. (1995). Task complexity and second language narrative discourse. Language Learning, 45, 99-140. http://dx.doi.org/10.1111/j.1467-1770.1995.tb00964.x

Rojas-Drummond, S.M., Albarrán, C.D., \& Littleton, K.S. (2008).Collaboration, creativity and the co-construction of oral and written texts, Thinking Skills and Creativity, 3, 177-191. http://dx.doi.org/10.1016/j.tsc.2008.09.008

Runco, M.A. (2003). Creativity, cognition, and their educational implications. In J.C.Houtz (Ed.), the educational psychology of creativity (pp. 25-56). Cresskill, NJ: Hampton Press.

Runco, M.A. (2004). Creativity. Annual review of Psychology, 55, 657-687. http://dx.doi.org/10.1146/annurev.psych.55.090902.141502

Runco, M.A. (2007). Creativity: Theories and themes: Research, development and practice. Amsterdam: Elsevier Academic Press.

Selvi, K. (2005). Learning and Creativity, Analecta Husserliana, 93, 351-370. http://dx.doi.org/10.1007/978-1-4020-5192-0_21

Sharples, M. (1999). How we write-Writing as creative design. London: Routledge.

Silvia, P.J. (2008). Discernment and Creativity: How Well Can People Identify Their Most Creative Ideas? Psychology of Aesthetics, Creativity, and the Arts, 2, 139-146. http://dx.doi.org/10.1037/1931-3896.2.3.139

Simonton, D. K. (1990). History, chemistry, psychology, and genius: An intellectual autobiography of historiometry. In R. S. Albert \& M. A. Runco (Eds.), Theories of creativity, 92-115. Newbury Park ; London: Sage Publications.

Skehan, P. (1989). Individual differences in second language learning. London: Edward Arnold. http://dx.doi.org/10.1017/S0272263100009979

Skehan, P. (1991). Individual differences in second language learning.Studies in second language acquisition, 13, 275-298.

Skehan, P., \& Foster, P. (1999).The influence of task structure and processing conditions on narrative retellings. Language Learning, 49, 93-120. http://dx.doi.org/10.1111/1467-9922.00071

Starko, A.J. (2010). Creativity in the classroom: Schools of curious delight (4th ed.). New York: Routledge.

Sternberg, R.J., \& Lubart, T.I. (1999).The concept of creativity: Prospects and paradigms. In R.J. Sternberg (Ed.), Handbook of creativity. Cambridge: University Press.

Sternberg, R.J. (2002). The theory of successful intelligence and its implications for language- aptitude testing. In P. Robinson (Ed.), individual differences and instructed language learning. Amsterdam: John Benjamins.

Sternberg, R.J. (2003). Creative thinking in the classroom. Scandinavian Journal of Educational Research, 47(3), 325-338. http://dx.doi.org/10.1080/00313830308595

Stubbs, M. (1997). An educational theory of (written) language. In: Bloor, T., Norrish, J. (Eds.), Written Language. Warwick.

Torrance, E. P. (1966). Torrance tests of creative thinking. Princeton, New Jersey: Personnel Press. 
van Dijk, T. A. (1997). The study of discourse. In van Dijk, Teun A. (Ed.), Discourse as Structure and Process. Sage Publications, London.

Vass, E. (2007). Exploring processes of collaborative creativity-The role of emotions in children's joint creative writing. Thinking Skills and Creativity, 2, 107-117. http://dx.doi.org/10.1016/j.tsc.2007.06.001

Weisberg, R. W. (1999). Creativity and knowledge: A challenge to theories. In R. J. Sternberg (Ed.), Handbook of creativity, 226-250. Cambridge: Cambridge University press.

Table 1. Results of correlation between narrative \& creativity

\begin{tabular}{|c|c|c|c|c|c|c|}
\hline Variables & & Total.Creativtiy & Cr.Fluency & Cr.Elaboration & Cr.Originality & Cr.Flexibility \\
\hline \multirow{2}{*}{ Narratives and Creativity } & Pearson Correlation & .126 & $.151^{*}$ & .044 & .107 & .072 \\
\cline { 2 - 7 } & Sig. (2-tailed) & .060 & .025 & .514 & .112 & .287 \\
\cline { 2 - 7 } & $\mathrm{N}$ & 222 & 222 & 222 & 222 & 222 \\
\hline
\end{tabular}

* Correlation is significant at the 0.05 level (2-tailed).

Table 2a. Results of one-way ANOVA for total creativity scores

\begin{tabular}{|c|c|c|c|c|c|}
\hline & Sum of Squares & df & Mean Square & F & Sig. \\
\hline Between Groups & 1590.333 & 2 & 795.167 & 5.215 & .006 \\
\hline Within Groups & 33391.365 & 219 & 152.472 & & \\
\hline Total & 34981.698 & 221 & & & \\
\hline
\end{tabular}

Table 2b. Results of Scheffe Post Hoc Test for total creativity

\begin{tabular}{|c|c|c|c|}
\hline \multirow{2}{*}{} & \multirow{2}{*}{$\mathrm{N}$} & \multicolumn{2}{|c|}{ Subset for alpha $=0.05$} \\
\cline { 3 - 4 } & & 1 & 2 \\
\hline Low & 74 & 132.9054 & \\
\hline Mid & 74 & 134.6216 & 134.6216 \\
\hline High & 74 & & 139.2432 \\
\hline Sig. & & .700 & .077 \\
\hline
\end{tabular}

Means for groups in homogeneous subsets are displayed. 
Table 3. Results of one-way ANOVA for creative elaboration scores

\begin{tabular}{|c|c|c|c|c|c|}
\hline & Sum of Squares & df & Mean Square & F & Sig. \\
\hline Between Groups & 40.171 & 2 & 20.086 & 1.808 & .166 \\
\hline Within Groups & 2433.000 & 219 & 11.110 & & \\
\hline Total & 2473.171 & 221 & & & \\
\hline
\end{tabular}

Table 4a. Results of one-way ANOVA for creative originality scores

\begin{tabular}{|c|c|c|c|c|c|}
\hline & Sum of Squares & df & Mean Square & F & Sig. \\
\hline Between Groups & 169.306 & 2 & 84.653 & 4.783 & .009 \\
\hline Within Groups & 3876.081 & 219 & 17.699 & & \\
\hline Total & 4045.387 & 221 & & & \\
\hline
\end{tabular}

Table 4b. Results of Scheffe Post Hoc Test for originality

\begin{tabular}{|c|c|c|c|}
\hline \multirow{2}{*}{} & \multirow{2}{*}{$\mathrm{N}$} & 1 & 2 \\
\cline { 3 - 4 } & & 34.7162 & \\
\hline Low & 74 & 36.0135 & 36.0135 \\
\hline Mid & 74 & & 36.8378 \\
\hline High & 74 & & .175 \\
\hline Sig. & & & \\
\hline \multicolumn{3}{|c|}{ Means for groups in homogeneous subsets are displayed. } \\
\hline
\end{tabular}


Table 5a. Results of one-way ANOVA for Creative flexibility scores

\begin{tabular}{|c|c|c|c|c|c|}
\hline & Sum of Squares & df & Mean Square & F & Sig. \\
\hline Between Groups & 61.649 & 2 & 30.824 & 3.091 & .047 \\
\hline Within Groups & 2183.689 & 219 & 9.971 & & \\
\hline Total & 2245.338 & 221 & & & \\
\hline
\end{tabular}

Table 5b. Results of Scheffe Post Hoc Test for flexibility

\begin{tabular}{|c|c|c|c|}
\hline \multirow{2}{*}{} & \multirow{2}{*}{$\mathrm{N}$} & 1 & 2 \\
\cline { 3 - 4 } & & 26.1081 & \\
\hline Low & 74 & 26.2027 & \\
\hline Mid & 74 & .856 & 27.2703 \\
\hline High & 74 & & \\
\hline Sig. & & & \\
\hline \multicolumn{3}{|c|}{ Means for groups in homogeneous subsets are displayed. } \\
\hline
\end{tabular}

Table 6a. Results of one-way ANOVA for creative fluency scores

\begin{tabular}{|c|c|c|c|c|c|}
\hline & Sum of Squares & df & Mean Square & F & Sig. \\
\hline Between Groups & 151.378 & 2 & 75.689 & 3.059 & .049 \\
\hline Within Groups & 5418.662 & 219 & 24.743 & & \\
\hline Total & 5570.041 & 221 & & & \\
\hline
\end{tabular}


Table 6b. Results of Scheffe Post Hoc Test for fluency

\begin{tabular}{|c|c|c|c|}
\hline \multirow{2}{*}{} & \multirow{2}{*}{$\mathrm{N}$} & 1 & 2 \\
\cline { 2 - 4 } & & & \multicolumn{2}{|c|}{ Subset for alpha =0.05 } \\
\hline Low & 74 & 49.8243 & \\
\hline Mid & 74 & 50.1892 & 50.1892 \\
\hline High & 74 & & 51.7297 \\
\hline Sig. & & .656 & .061 \\
\hline
\end{tabular}

